УДК 101.1

DOI: 10.18101/1994-0866-2020-1-66-72

\title{
ПОНЯТИЕ ЧЕЛОВЕЧЕСКОЙ ЛИЧНОСТИ В ЭКЗИСТЕНЦИАЛЬНОЙ ТРАДИЦИИ
}

\author{
() Рукин Александр Валентинович \\ кандидат философских наук, доцент кафедры гуманитарных и социально- \\ экономических дисциплин, \\ Военная академия воздушно-космической обороны имени Маршала Советского \\ Союза Г. К. Жукова \\ Россия, 170100, г. Тверь, ул. Жигарева, 50 \\ E-mail: rukin.tver@yandex.ru
}

Человек и его жизненный путь традиционно являются самыми сложными объектами научного исследования. Современные методы познания не позволяют раскрыть многогранную природу человека и ответить на вопросы о конечных целях человеческой жизни. В современной науке не выработан единый подход к пониманию человека. Обращаясь к историческому наследию, исследователи человеческой личности стремятся найти ответы на вопросы о сущности человека и его индивидуальном способе существования. Экзистенциалисты внесли значительный вклад в развитие представлений о свободной личности. В экзистенциальной модели утверждается творческий, духовный и свободный человек. Свобода человека проявляется в его свободном выборе, за который несет ответственность сам человек. В аспекте доминирования внутренних факторов, обусловливающих развитие человека, экзистенциальная модель противопоставляется социологическому подходу. В экзистенциальной традиции природа человека рассматривается в неразрывной взаимосвязи с его индивидуальным способом существования.

Ключевые слова: человек; свобода; существование; сущность человека; жизненный путь человека; выбор; ответственность; экзистенциализм.

\section{Для цитирования}

Рукин А. В. Понятие человеческой личности в экзистенциальной традиции // Вестник Бурятского государственного университета. Философия. 2020. Вып. 1. С. 66-72.

Исследования человека-индивида получили значительное развитие в экзистенциалистских концепциях XX в. На становление экзистенциализма большое влияние оказала философия Н. А. Бердяева и Л. И. Шестова, которые осуществили экзистенциалистскую критику рационалистической модели человека, определяя свободу как главное свойство, атрибут личности.

Н. А. Бердяев формирует духовно-экзистенциальную модель человека. В решении ключевого методологического вопроса он подчеркивает, что существование индивида предшествует формированию его сущности, личность в процессе творения своей индивидуальной жизни самосозидается. Индивид творит себя, но, создавая себя, создает и свой жизненный путь. «Личность в начале пути, и она лишь в конце пути» [2, с. 13]. 
По Бердяеву, человек свободен в выборе самого себя и в силу этого ответственен перед Богом за то, каким он стал в процессе своей жизни. Таким образом, жизнь личности может рассматриваться как средство, необходимое индивиду для выполнения задания Бога. Жизнь индивида наполняется экзистенциальным смыслом, ибо «само существование личности предполагает жертву и нет жертвы без личности» [2, с. 63]. Он против подчинения личности обществу, интересы общества, нации, человеческого рода, природы не могут быть выше интересов личности, «личность не есть часть универсума, универсум есть часть личности, ее качества» $[1$, с. 13$]$.

Таким образом, Бердяев развивает модель духовного, творческого, свободного человека. Если для Гегеля дух человека проявляет себя как дух познающий, то для Бердяева дух определяется экзистенциальным содержанием. Дух определяет поступки человека, «дух конституирует личность, несет просветление и преображение биологического индивидума, делает личность независимой от природного порядка» [2, с. 63].

Проблема жизни человека является центральной в творчестве Шестова. Он ясно высветил тему трагической сущности человеческого бытия, неисчерпаемость человеческого страдания, также искал освобождения от порабощающей власти необходимости, закрепленной и подтвержденной разумом. Для Шестова всегда оставалась принципиальной иррациональность бытия человека. «Знание не привело человека к свободе... знание закрепостило нас, отдало на поток и разграбление" вечным истинам» $[9$, с. 23].

«Разумный» человек, по Шестову, в один прекрасный день обнаруживает, что «какая-то невидимая сила похитила у него самое драгоценное его сокровище - его свободу» [10, с. 448]. Рационализация человеческой жизни, поклонение научным истинам уничтожают неповторимую индивидуальность личности, унифицирует мысли и образ жизни. Главным условием человеческого счастья является свобода. Свобода же противоположна рациональности. По Шестову, попытки организации общества по «законам разума» тщетны в силу иррациональности бытия. Рамки общепринятых норм самого разумно организованного общества тесны для человеческой индивидуальности. Рациональная, расчетливая, благополучная жизнь - это не жизнь уже, а начало смерти. Для Шестова человек - существо духовное. Дух неуничтожим материальными средствами, душу нельзя убить пулей, но на дух можно воздействовать духом. По Шестову, человек сам творит не только свой земной жизненный путь, но и собственную метафизическую судьбу.

Таким образом, для Шестова очевиден примат личности над обществом. Свобода - главное свойство личности. Индивид активен в формировании своей земной жизни и развитии духа.

Хайдеггер не считал себя экзистенциальным философом, однако его идеи о природе человека имеют экзистенциальный характер. М. Хайдеггер, виртуоз двусмысленности, рассматривает единство времени и бытия человека. Для Хайдеггера: «бытие не есть. Бытие имеет место как выход присутствия из пота- 
енности» [7, с. 394]. Бытие человека рассматривается как присутствие, как то, что имеет место быть в настоящем. Бытие рассматривается как то, чем отмечено всякое сущее, а человек не только присутствует, но и впускает это присутствие. Жизненный путь личности представляется как постоянная и индивидуальная открытость бытию. Для человека его настоящее является важным, так как оно определяет его прошлое и будущее. В свою очередь, человек в своем настоящем испытывает влияние своего прошлого и будущего, причем характер этого влияния для каждого человека индивидуален.

В свете хайдеггеровского понимания бытия как присутствия, впускания присутствия жизненный путь человека представляется как непрерывный процесс выхода присутствия из потаенности. Причем человек сам отвечает за то, кем является в настоящий момент, так как он определяет, какое присутствие допускает из потаенности.

Рассмотрение бытия человека в аспекте времени обращает взгляд человека на свое будущее, этот поиск возможного присутствия в потаенности волнует человека, так как выход этого присутствия из потаенности определяет ту ситуацию, в которой он может оказаться. «В будущем, в наступающем нас достает присутствие» [7, с. 398-399].

Индивидуальный образ жизни человека в настоящем не проходит для него бесследно и оказывает влияние на дальнейшее разворачивание его жизненного пути. Бытие человека в настоящем является необходимым условием, обусловливающим то, каким он станет в будущем, ибо он впускает это бытие в настоящем. Настоящее представляется условием, определяющим будущее, хотя будущее всегда возможность в отличие от настоящего, которое является действительностью. Однако дальнейшее формирование жизненного пути индивида зависит от конкретного способа его существования в настоящем.

Будущее задевает человека своим особым образом и особым образом влияет на формирование его жизненного пути. То, что есть из себя индивид в настоящем и каким образом он проявляет свою сущность, определяет то, каким станет человек в будущем. Человек своим настоящим, тем, кто он есть в настоящем, определяет свой дальнейший индивидуальный жизненный путь.

Для Хайдеггера человек, прежде всего, есть не то, каким он уже стал, как это было у Гегеля, напротив, главное в человеке - это то, каким он еще не стал - его индивидуальная возможность. Если внимание Гегеля устремлено на настоящее, определяемое прошлым, то внимание Хайдеггера сосредоточено на будущем. Если для Гегеля понять - значит вскрыть необходимость, то для Хайдеггера понять - значит увидеть возможность.

На бытие человека оказывает воздействие не только непосредственно окружающая действительность, настоящее, но и отсутствие этого настоящего, то есть прошлое, которое воздействует особым образом. С течением времени человек наиболее значимые события своего прошлого, как правило, оценивает в ином свете, нежели в момент их свершения. Прошлое напоминает о себе и так или иначе влияет на настоящее человека. 
В плане жизненного пути человека индивид постоянно испытывает влияние своего прошлого, и тем самым прошлое оказывает влияние на дальнейшее формирование его жизненного пути. Настоящее определяет прошлое, и раз прошлое влияет особым образом на жизненный путь человека, то важное значение имеет, каким именно является это настоящее. Плохое настоящее в будущем сформирует плохое прошлое, а плохое прошлое может угнетать настоящую жизнь человека.

Таким образом, Хайдеггер рассматривает человека как участника и творца своих индивидуальных свойств и своего личностного жизненного пути. Индивид становится ответственным за то, кем он стал и за свой жизненный путь. Он показывает противоречивую связь настоящего, прошлого и будущего в жизни человека.

Человек испытывает обусловливающее влияние своего прошлого и тем самым прошлое оказывает влияние на неповторимость его настоящего. Прошлое человека индивидуально, индивидуально и его отношение к своему прошлому. Настоящее в течение жизни постоянно переходит в прошлое, формируя и определяя его, таким образом, человек своим настоящим активно формирует свое прошлое, то есть то, что влияет на его жизнь в настоящем. Он сам формирует этот воздействующий фактор и тем самым формирует свою жизнь.

Настоящее человека является основой его будущего. Человек может мыслить свое будущее как возможность своего настоящего, и в силу этого индивид активен в формировании своих личностных свойств и своего индивидуального жизненного пути. Тем самым настоящее становится важным для человека, так как настоящее определяет его будущее.

Абсолютизация свободы человека является основой экзистенциальной модели индивидуальной жизни человека, разработанной Жан-Полем Сартром. Сартр считает, что человек - это не что иное, как тот проект, который им самим конструируется, это то, что каждый решается сделать со своей жизнью. Человек и его жизненный путь характеризуются самоопределением, а не предопределением. Нет никакой «природной» или «божественной» сущности, которая могла бы предрешать поведение и мышление, тем более неверно было бы приписывать человеку предопределение его жизненного пути свыше.

Сартр рассматривает самоопределение индивида и выбор личностного жизненного пути в плоскости моральных норм. Внешняя среда не рассматривается как нечто противостоящее человеку, индивид непосредственно влияет на внешнюю среду, выбирая себя. Конкретно-историческая ситуация только «окрашивает» жизненный путь личности. «Человек живет своей жизнью, он создает свой облик, а вне этого облика ничего нет» [6, с. 333]. Человек абсолютно свободен и сам себя создает, то есть личное решение человека определяет выбор самого себя. Человек сам выбирает свой образ жизни и живет своей индивидуальной жизнью. Ответственность за свои личностные качества несет сам человек, в силу этого человек ответственен и за свой выбор.

В мировоззрении Сартра неповторимость жизненного пути индивида является результатом его свободного выбора. Человек просто существует, он не та- 
кой, каким себя представляет, но такой, каким он хочет стать. И поскольку он представляет себя уже после того, как начинает существовать, и проявляет свою волю после того, как начинает существовать, то он есть лишь то, что сам из себя делает. Первый спонтанный порыв к личностному существованию, определяемый природой личности и выражающийся в желании стать именно таким, делает индивида тем, кто он есть. «Человек - это прежде всего проект, который переживается субъективно. Ничто не существует до этого проекта, нет ничего на умопостигаемом небе, и человек станет таким, каков его проект бытия» [6, c. 323].

Таким образом, Сартр не исследует жизненный путь человека в прямой постановке, однако анализ его философских взглядов позволяет сделать вывод о том, что человек в силу своей неограниченной свободы сам создает себя и свой жизненный путь. Ответственность за своеобразие личностных качеств человека Сартр возлагает на самого индивида, в том числе и за поступки, которые человек совершает в процессе своего жизненного пути, ибо «... экзистенциализм отдает каждому человеку во владение его бытие и возлагает на него полную ответственность за существование» [6, с. 323].

Альбер Камю продолжает развитие экзистенциальной модели индивидуальной жизни человека. Он показывает иллюзорность единства мира и человека. В результате взаимоотношения человека с внешним социальным миром у человека возникает чувство абсурда, ибо сам по себе мир просто неразумен, и это все, что о нем можно сказать. Иррациональность мира отдаляет человека от этого мира. Абсурдно столкновение между иррациональностью и иступленным желанием ясности, зов которого отдается в глубинах человеческой души. Абсурд равно зависит и от человека, и от мира, абсурд единственная связь между ними.

Стремление человека к рациональному объяснению мира наталкивается на иррациональность мира. Осознание этого противоречия и есть абсурд. «Абсурд - это ясный разум, осознающий свои пределы» [3, с. 50]. Осознание этого абсурда, осознание своих пределов в рациональном объяснении мира, за которые человек не может выйти, и сжигающее желание ясности приводят индивида в состояние болезненной страсти. «Абсурдность становится болезненной страстью с того момента, как осознается» [3, с. 35].

Камю не рассматривает в прямой постановке проблему жизненного пути личности, однако его экзистенциальный подход к индивидуальной жизни человека позволяет выделить судьбоносные моменты в разворачивании жизненного пути индивида: прежде всего моменты, когда возникающее чувство абсурдности приводит к переоценке былых ценностей, когда утрачивается смысл жизни и человек оказывается перед проблемой выбора. Для человека этот момент является судьбоносным, в результате разрешения которого либо его жизнь прекращается, либо начинается новый период жизни.

В каждом случае абсурдность порождается сравнением. Чувство абсурдности рождается не из простого исследования факта или впечатления, но врывается вместе со сравнением фактического положения дел с какой-то реальностью, 
сравнением действия с лежащим за пределами этого действия миром. По существу абсурд есть раскол. Его нет ни в одном из сравниваемых элементов. Он рождается в их столкновении, «... абсурд не в человеке и не в мире, но в их совместном присутствии» [3, с. 39].

Камю оставляет индивиду два пути выхода из состояния жгучей страсти. Первый - самоубийство, второй - бунт. Для Камю смирение - это самоубийство, абсурдный человек должен проявить настойчивость, бунт. «Для человека без шор нет зрелища прекраснее, чем борьба интеллекта с превосходящей его реальностью. Ни с чем не сравнимо зрелище человеческой гордыни, тут ничего не могут поделать все самоуничтожения» [3, с. 53].

Жить жизнью человека - значит пробуждать к жизни абсурд. Пробуждать его к жизни - значит не отрывать от него взора. Кьеркегоровскую стадию религиозности Камю заменяет стадией красоты, ибо без красоты не может быть ни справедливости, ни истины, ни свободы. Абсурд - это противоречие, которое приводит человека к осознанию себя и своего места в мире, это этап осмысления мира. В результате абсурда, порождающего духовный конфликт, рождается новая индивидуальность, которая возвращается в повседневность как личность бунтующая.

Творчество Камю играет большую роль в осмыслении индивидуальной жизни человека. Он отразил важные стороны процесса внутренних изменений, происходящих в сущности индивида в ходе его жизненного пути, подчеркнул противоречивость процесса переоценки человеком своих ценностей.

Таким образом, в экзистенциальной модели человек рассматривается как творческое существо, способное к саморазвитию; духовное существо, причем именно дух определяет неповторимость и уникальность личности; свободное существо, способное осуществлять свой личностный выбор и нести за свой выбор ответственность.

Проведенный ретроспективный анализ эволюции экзистенциального осмысления природы человека как субъекта жизни и смысла его индивидуального жизненного пути свидетельствует, что в истории философской мысли не выработана целостная и непротиворечивая теория как самого человека, так и его жизненного пути. Однако несомненным является то, что благодаря усилиям экзистенциальных философов накоплен богатый потенциал знаний, который создает основу дальнейшего социально-философского постижения природы человека и его индивидуальной жизни.

\section{Литература}

1. Бердяев Н. А. Царство духа и царство кесаря. М.: Республика, 1995. 375 с.

2. Бердяев Н. А. О назначении человека: сб. М.: Республика, 1993. 382 с.

3. Камю А. Бунтующий человек. Философия. Политика. Искусство. М.: Политиздат, 1990. $415 \mathrm{c}$.

4. Кьеркегор С. Наслаждение и долг. Киев: AirLand, 1994. 504 с.

5. Кьеркегор С. Понятие страха // Страх и трепет. М., 1993. 383 с. 
6. Сартр Ж. П. Экзистенциализм это гуманизм // Сумерки богов. М.: Политиздат, 1990. С. 319-344.

7. Хайдеггер М. Время и бытие: статьи и выступления. М.: Республика, 1993. 445 с.

8. Хайдеггер М. Время и бытие. М.: Республика, 1993. С. 192-220.

9. Шестов Л. Киргегард и экзистенциальная философия. М.: Прогресс-Гнозис, 1992. $304 \mathrm{c}$.

10. Шестов Л. Афины и Иерусалим // Сочинения: в 2 т. М.: Наука, 1993. Т. 1. 560 с.

\section{THE CONCEPT OF A HUMAN PERSON IN EXISTENTIAL TRADITION}

Aleksandr V. Rukin

Cand. Sci. (Philos.), A/Prof. of Department of the Humanities and Socio-Economic Disciplines,

Zhukov Air and Space Defense Academy

50 Zhigaryova St., Tver 170100, Russia

E-mail: rukin.tver@yandex.ru

The human and his path of life are traditionally the most complex objects of scientific research. Modern methods of cognition do not allow us to reveal the multifaceted human nature and answer the questions about the ultimate goal of human life. There is no a unified approach to comprehension of the human in modern science. Referring to the historical heritage, researchers of the human person attempt to answer the questions about the human essence and the individual mode of existence. Existentialists have made a significant contribution to the development of ideas of the free individual. The existential model affirms a creative, intellectual, and free person. A person's freedom is manifested in his free choice, for which the person himself is responsible. The existential model in the aspect of dominating internal factors that determine human development is opposed to the sociological approach. Existential tradition considers the human nature in symbiotic relationship with the individual mode of existence.

Keywords: human; freedom; existence; the human essence; the human path of life; choice; responsibility; existentialism. 